\title{
Clinical and epidemiological profile of patients with valvular heart disease admitted to the emergency department
}

\author{
Aspectos clínicos e epidemiológicos de portadores de doença valvar \\ atendidos em unidade de pronto atendimento
}

\author{
Ricardo Casalino Sanches de Moraes ${ }^{1}$, Marcelo Katz ${ }^{2}$, Flávio Tarasoutch ${ }^{1}$
}

\begin{abstract}
Objective: To evaluate the clinical and epidemiological profile of patients with valvular heart disease who arrived decompensated at the emergency department of a university hospital in Brazil. Methods: A descriptive analysis of clinical and echocardiographic data of 174 patients with severe valvular disease, who were clinically decompensated and went to the emergency department of a tertiary cardiology hospital, in the State of São Paulo, in 2009. Results: The mean age of participants was $56 \pm 17$ years and $54 \%$ were female. The main cause of valve disease was rheumatic in $60 \%$, followed by $15 \%$ of degenerative aortic disease and mitral valve prolapse in $13 \%$. Mitral regurgitation $(27.5 \%)$ was the most common isolated valve disease, followed by aortic stenosis $(23 \%)$, aortic regurgitation $(13 \%)$ and mitral stenosis $(11 \%)$. In echocardiographic data, the mean left atrial diameter was $48 \pm 12 \mathrm{~mm}, 38 \pm 12 \mathrm{~mm}$ for the left ventricular systolic diameter, and $54 \pm 12 \mathrm{~mm}$ for the diastolic diameter; the mean ejection fraction was $56 \pm 13 \%$, and the mean pulmonary artery pressure was $53 \pm 16 \mathrm{mmHg}$. Approximately half of patients (44\%) presented atrial fibrillation, and over one third of them (37\%) had already undergone another cardiac surgery. Conclusion: Despite increased comorbidities and age-dependent risk factors commonly described in patients with valvular heart disease, the clinical profile of patients arriving at the emergency department represented a cohort of rheumatic patients in more advanced stages of disease. These patients require priority care in high complexity specialized hospitals.
\end{abstract}

Keywords: Heart valve diseases/epidemiology; Rheumatic fever/ complications

\section{RESUMO}

Objetivo: Avaliar o perfil clínico e epidemiológico dos pacientes com doença valvar que chegaram descompensados no pronto atendimento de um hospital universitário de referência nacional. Métodos: Análise descritiva de dados clínicos e ecocardiográficos de 174 pacientes consecutivos portadores de doença valvar grave, que apresentaram descompensação clínica e procuraram atendimento no pronto-socorro de um hospital terciário de cardiologia do Estado de São Paulo no ano de 2009. Resultados: Dos 174 pacientes avaliados, a média etária foi de $56 \pm 17$ anos e $54 \%$ eram do gênero feminino. A principal etiologia da doença valvar foi a reumática $(60 \%)$, seguida pela doença degenerativa aórtica (15\%) e pelo prolapso mitral (13\%). A valvopatia mais comumente observada de forma isolada foi a insuficiência mitral $(27,5 \%)$, seguida por estenose aórtica $(23 \%)$, insuficiência aórtica $(13 \%)$ e estenose mitral $(11 \%)$. Nos dados ecocardiográficos, a média do diâmetro do átrio esquerdo foi de $48 \pm 12 \mathrm{~mm}$, do ventrículo esquerdo na sístole foi de $38 \pm 12 \mathrm{~mm}$, e diástole foi de $54 \pm 12 \mathrm{~mm}$; a média da fração de ejeção foi de $56 \pm 13 \%$ e a pressão pulmonar média foi de $53 \pm 16 \mathrm{mmHg}$. Aproximadamente metade dos pacientes $(44 \%)$ estava em fibrilação atrial, e mais de um terço dos pacientes (37\%) já havia sido submetido a outra cirurgia cardíaca. Conclusão: Apesar do aumento das comorbidades e dos fatores de risco idade dependentes comumente descritos nos portadores de cardiopatia valvar, o perfil clínico dos sujeitos que chegaram ao pronto atendimento representou uma coorte de pacientes reumáticos em estágios mais avançados de doença. Esses pacientes requerem atendimento prioritário em serviço especializado de alta complexidade.

Descritores: Doenças das valvas cardíacas/epidemiologia; Febre reumática/ complicações

\section{INTRODUCTION}

The rheumatic etiology prevails as the main cause of valvular heart disease in Brazil, ${ }^{(1)}$ and it is quite different from Europe and the United States, where the disease is mainly caused by degenerative conditions. ${ }^{(2)}$

\footnotetext{
1 Instituto do Coração, Faculdade de Medicina, Universidade de São Paulo, São Paulo, SP, Brazil.

${ }^{2}$ Hospital Israelita Albert Einstein, São Paulo, SP, Brazil.

Corresponding author: Ricardo Casalino Sanches de Moraes - Unidade de Valvopatia Clínica, Instituto do Coração, Faculdade de Medicina, Universidade de São Paulo, Avenida Dr. Enéas de Carvalho Aguiar, 44 - Cerqueira César - CEP: 05403-900 - São Paulo, SP, Brazil - Phone: (55 11) 2661-5000 - E-mail: ricardo.moraes@einstein.br

Received on: Nov 26, 2013 - Accepted on: Apr 16, 2014

Conflict of interest: none.

DOI: 10.1590/S1679-45082014A03025
} 
The population is aging in Brazil. Life expectancy at birth, according to data from the Information Technology Department of the Unified Health System (DATASUS), is roughly 73 years $^{(3)}$ and this aging has increased the diagnosis of degenerative etiology valve diseases, frequently accompanied by age-dependent comorbidities.

This kind of patient is a real challenge to the general practitioner at the front line of care, given comorbidities plus underlying valve disease make treatment complex, and clinical outcomes are not always satisfactory.

In view of this increasing complexity, specialists in valve disease have proposed at cardiology associations a multidisciplinary professional team (the heart team) approach for these patients, including cardiologists, chest physicians, geriatrists, heart surgeons, dietitians, radiologists, hemodynamic specialists and psychologists, among others.

University hospitals are essential parts of the Brazilian health system, because they are references for highly complex cases in the entire national territory. However, due to the difficulties in access found in our health system, patients who should receive preventive care at the initial stages of valve heart disease at primary care units eventually reach tertiary and quaternary hospitals at advanced stages of the valve heart condition, requiring urgent intervention through the emergency department.

The clinical characteristics and comorbidities of patients with valve heart disease who arrive decompensated at the emergency department have not been acknowledged. Therefore, it is essential for the general practitioner to acknowledge the epidemiological, clinical and echocardiographic profile of individuals with valve disease who arrive at the emergency department.

\section{OBJECTIVE}

To evaluate the epidemiological, clinical and echocardiographic profile of patients with valvular heart disease who arrive decompensated at the emergency department of a national reference university hospital.

\section{METHODS}

A descriptive analysis of clinical and echocardiographic data of 174 consecutive patients with severe valve disease, who arrived clinically decompensated at the emergency department, and were admitted to a tertiary cardiology hospital in the State of São Paulo, in 2009.

All patients included had valve heart disease as their main diagnosis and cause of their clinical instability.
Regardless of the type of valve disease, it was confirmed by the clinical valve disease unit team, and through echocardiographic assessment. All patients were functional class III/IV of the New York Heart Association.

The clinical profile variables collected upon admission were:

- Age

- Gender

- Underlying valve disease

- Etiology of valve disease (based on clinical history, physical exam and echocardiography)

- Comorbidities: hypertension defined as blood pressure $>140 \times 90 \mathrm{mmHg}$ or use of antihypertensive drugs; diabetes mellitus defined as need for oral hypoglycemic agents and/or insulin; coronary artery disease; peripheral artery disease or previous neurological disorder

- Previous heart surgery

- Presence of valve prosthesis

- Atrial fibrillation (paroxistical, persistent and permanent)

- Medication taken by patient

The echocardiogram after admission registered: left atrial and both ventricular diameters; pulmonary artery systolic pressure (PASP); diastolic function (ventricular filling pattern); left ventricular ejection fraction (LVEF); estimate of right ventricular function; and analysis of valves. PASP was classified into two groups: high pressure, if PASP $>30 \mathrm{mmHg}$, and normal, if PASP $<30 \mathrm{mmHg}$. LVEF $>50 \%$ was considered normal and LVEF $<50 \%$, decreased.

Continuous variables were expressed as mean and standard deviation (normal distribution), and median and interquartile variation (asymmetrical distribution). Categorical variables were expressed as absolute and relative frequencies. The study protocol was approved by the Research Project Analysis Ethics Committee (Cappesq) on April 7, 2010, with protocol number 0155/10.

\section{RESULTS}

Among the 174 patients evaluated, the mean age was $56 \pm 17$ years and $54 \%$ were female. The main valve etiology was rheumatic in $60 \%$, followed by degenerative disease in $15 \%$ of patients (Table 1 ). The most frequently observed isolated valve disease was mitral regurgitation $(27.5 \%)$, followed by aortic stenosis $(23 \%)$. In relation to comorbidities, $51 \%$ had hypertension, $16 \%$ diabetes mellitus and $44 \%$ atrial fibrillation. Over one third of patients had already been submitted to another heart valve surgery and $95 \%$ had a biological prosthesis. Valve 
prosthesis dysfunction was the reason for admission for $9.2 \%$; the main prosthesis was mitral, in $8.1 \%$, followed by the aortic. Associated coronary artery disease was found in $17 \%$ of patients (Table 1 ).

Table 1. Patients' characteristics

\begin{tabular}{lc}
\hline Clinical findings & Mean and/or \% \\
\hline Age, years & $56 \pm 17$ \\
Female & 54 \\
Hypertension & 51 \\
Diabetes mellitus & 16 \\
Atrial fibrillation & 44 \\
Reoperations & 37 \\
Valve disease & \\
Mitral regurgitation & 27,5 \\
Aortic stenosis & 23 \\
Aortic regurgitation & 13 \\
Mitral stenosis & 11 \\
Etiology & \\
Rheumatic & 60 \\
Aortic degenerative disease & 15 \\
Mitral valve prolapse & 13 \\
Endocarditis & 9 \\
Others* & 3 \\
\hline
\end{tabular}

* Bicuspid aortic disease, ischemic disease and aneurysm and aorta dissection.

Regarding medication use, $80 \%$ were on diuretics, $55 \%$ on angiotensin-converting enzyme inhibitors, $33 \%$ on aldosterone antagonists, $44 \%$ on digoxin, $35 \%$ on beta blockers, $17 \%$ on aspirin, $25 \%$ on anticoagulants and $10 \%$ on amiodarone (Table 2).

Table 2. Medication used

\begin{tabular}{lc}
\hline Medication & Use (\%) \\
\hline Diuretics & 80 \\
Angiotensin-converting enzyme inhibitors & 55 \\
Angiotensin II receptor inhibitors & 12 \\
Calcium antagonists* & 13 \\
Digoxin & 44 \\
Beta blockers** & 35 \\
Aldosterone antagonist & 33 \\
Aspirin & 17 \\
Anticoagulants & 25 \\
Statins & 27 \\
Amiodarone & 10 \\
Hydralazine/nitrate & 12 \\
\hline
\end{tabular}

* The main calcium antagonist taken was amlodipine; ** the main beta blocker taken was carvedilol.

As to echocardiographic parameters (Table 3), the mean left ventricle dimension on systole was $38 \pm 12 \mathrm{~mm}$, and on diastole, $54 \pm 12 \mathrm{~mm}$. Mean LVEF was $56 \pm 13 \%$.
Table 3. Echocardiographic parameters

\begin{tabular}{lc}
\hline Echocardiography & Values \\
\hline Left atrium, mm & $48 \pm 12$ \\
LVSD, mm & $38 \pm 12$ \\
LVDD, mm & $54 \pm 12$ \\
LVEF, \% & $56 \pm 13$ \\
PASP, mmHg & $53 \pm 16$ \\
\hline LVSD: left ventricular systolic diameter LVDD: left ventricular diastolic diameter; LVEF: left ventricular ejection fraction; \\
PASP: pulmonary artery systolic pressure.
\end{tabular}

LVEF was classified as normal (LVEF $>50 \%$ ) in $77 \%$, and decreased $(\mathrm{LVEF}<50 \%)$ in $23 \%$. Mean PASP was $53 \pm 6 \mathrm{mmHg}$, in that $55 \%$ of patients had a high pulmonary pressure (PASP $>30 \mathrm{mmHg}$ ) and $45 \%$ had a PASP $<30 \mathrm{mmHg}$. All patients were in functional class III or IV upon admission at the emergency department and the main reason for clinical decompensation was progression of the uderlying disease. Most patients had already been assessed by specialists at the outpatient clinic, and over $90 \%$ of them were already programmed for surgery due to progression of symptoms and echocardiography parameters.

\section{DISCUSSION}

The main findings of the present study were: most patients with valve disease seen at the emergency department had rheumatic etiology; despite the main rheumatic etiology, the mean age of patients was above what is expected for this etiology; a significant part of patients seen had already been submitted to heart surgery; most patients seen were already scheduled for surgery.

In rheumatic disease, the eradication of the infectious condition of the oropharynx would abort the emergence of immune disease and its complications. ${ }^{(4)}$ However, in Brazil, primary care and access to health services are far from ideal, and rheumatic fever still has a high incidence. In our study, in fact, the rheumatic etiology was the most frequent. In general, rheumatic patients are affected at an earlier age (school and adolescence) and, depending on the degree of valve involvement, consequences can appear at very early ages. There is predominance in female patients and the mitral valve is the most affected.

In our study, most patients were women and mitral involvement was very common. However, the mean age of patients was above expected (considering rheumatic etiology). We highlight that patients had more advanced stage valve disease characterized by previous valve surgery and the frequent presence of atrial fibrillation and pulmonary hypertension. 
In the natural history of valve heart disease, the presence of valve disease-related symptoms is the main indication for repair. However, some echocardiographic parameters, such as ventricular function, pulmonary artery pressure and ventricular diameters, are also taken into account to indicate intervention. ${ }^{(1)}$ Particularly, atrial fibrillation and pulmonary hypertension also have prognostic meaning. Pulmonary artery pressure is related to an increased risk of death and heart failure. ${ }^{(5)}$

Atrial fibrillation, which is responsible for reducing cardiac output and predisposes to thromboembolic events, ${ }^{(6)}$ also is an independent predictor of risk of death in the postoperative period of heart surgery, as exposed in the STS risk score. ${ }^{(7)}$

Another striking characteristic of this population was the number of previous surgeries that, in this case, can be explained by the rheumatic etiology, in which the first surgery occurred at a young age, with the preference of the organization for biological prostheses. This choice is guided by two main reasons: the chronic use of anticoagulants would make pregnancy difficult in women at child-bearing age given the medication is mandatory with a mechanical prosthesis, unlike bioprostheses; second, the difficult access to medical care and the low level of schooling would be inversely related to appropriate compliance to and control of oral anticoagulants. ${ }^{(8)}$

Regarding surgery in youth, we know that the durability of a biological prosthesis can be of up to 15 to 20 years in the best scenarios, but its dysfunction may happen at any moment during follow-up. This fact would be one more factor to explain the high incidence of reoperations.

The mean ventricular function was not as low as expected in a population with important symptoms (functional classes III/IV), but many cases were of individuals with single or combined mitral regurgitation, which knowingly overestimates ventricular function.

Most patients had already been assessed by a specialist in the outpatient clinic and over $90 \%$ of them were already scheduled for surgery. However, due to the imbalance between demand and availability for intervention in a programmed surgical procedure, in many cases patients were on hold for treatment, and were followed by clinical outpatient care. During this period, many patients were eventually admitted to hospital in unfavorable conditions and at advanced stages of poor heart adaptation. Non-programmed surgery, as an emergency, is a reality in our country due to high demand, poor distribution and poor organization of the healthcare system. This delay has already been described in other centers in the world. ${ }^{(9)}$
Surgery triggered through the emergency department is an independent variable for operative risk and, in the main heart surgery risk scores, such as the EuroSCORE, it represents an independent risk variable. ${ }^{(10)}$

\section{LIMITATION}

The present study is descriptive of one center and limited in time. There are no inferential possibilities. However, it adds relevant information on the "real world" given it was performed at a high complex valve heart disease reference center.

\section{CONCLUSION}

Despite increase in comorbidities and age-dependent risk factors commonly described in individuals with valvular heart disease, the clinical profile of patients who present at the emergency department represented a typical cohort of rheumatic patients at more advanced stages of the disease. Mitral disease, young patients (in comparison to international valve disease cohorts), high rate of reoperations and pulmonary hypertension prevailed. These patients require priority care at high complexity specialized services.

\section{REFERENCES}

1. Tarasoutchi F, Montera MW, Grinberg M, Barbosa MR, Piñeiro DJ, Sánchez CR, et al. Diretriz Brasileira de Valvopatias - SBC 2011/I Diretriz Interamericana de Valvopatias - SIAC 2011. Arq Bras Cardiol. 2011;97(5):1-67.

2. Moraes RC. Validação do EuroSCORE em valvopatas submetidos a cirúrgia cardíaca [tese]. São Paulo: Universidade de São Paulo; 2013.

3. Brasil. Ministério da Saúde. Secretaria Executiva. Datasus. Informações de Saúde. Indicadores de Saúde [Internet]. [citado 2013 Nov 1]. Disponível em: http://datasus.gov.br

4. Barbosa PJ, Müller RE, Latado AL, Achutti AC, Ramos Al, Weksler C, et al. Diretrizes Brasileiras para Diagnóstico, Tratamento e Prevenção da Febre Reumática da Sociedade Brasileira de Cardiologia, da Sociedade Brasileira de Pediatria e da Sociedade Brasileira de Reumatologia. Arq Bras Cardiol. 2009;93(3 Supl.4):1-18.

5. Barbieri A1, Bursi F, Grigioni F, Tribouilloy C, Avierinos JF, Michelena HI Rusinaru D, Szymansky C, Russo A, Suri R, Bacchi Reggiani ML, Branzi A, Modena MG, Enriquez-Sarano M; Mitral Regurgitation International DAtabase (MIDA) Investigators. Prognostic and therapeutic implications of pulmonary hypertension complicating degenerative mitral regurgitation due to flail leaflet: a multicentre long-term international study. Eur Heart J. 2011;32(6):751-9.

6. de Almeida Brandão CM, Pomerantzeff PM, Souza LR, Tarasoutchi F, Grimberg $\mathrm{M}$, Ramires JA, et al. Multivariate analysis of risk factors for hospital mortality in valvular reoperations for prosthetic valve dysfunction. Eur $\mathrm{J}$ Cardiothorac Surg. 2002;22(6):922-6.

7. O'Brien SM1, Shahian DM, Filardo G, Ferraris VA, Haan CK, Rich JB, Normand SL, DeLong ER, Shewan CM, Dokholyan RS, Peterson ED, Edwards FH, Anderson RP; Society of Thoracic Surgeons Quality Measurement Task Force. The Society of Thoracic Surgeons 2008 cardiac surgery risk models: part 2-isolated valve surgery. Ann Thorac Surg. 2009;88(1 Suppl):S23-42 
8. Bocchi E, Guimaraes G, Tarasoutchi F, Spina GS, Manguini S, Bacal F. Cardiomyopathy, adult valve disease, and heart failure in South America. Heart (London). 2009;95(3):181-9.

9. Koomen EM, Hutten BA, Kelder JC, Redekop WK, Tijssen JG, Kingma JH.
Morbidity and mortality in patients waiting for coronary artery bypass surgery. Eur J Cardiothorac Surg. 2001;19(3):260-5.

10. Nashef SA, Roques F, Sharples LD, Nilsson J, Smith C, Goldstone AR, et al EuroSCORE II. Eur J Cardiothorac Surg. 2012;41 (4):734-44; discussion 744-5. 